\title{
KARAKTER GOTONG ROYONG WARGA DALAM MENGHADAPI BENCANA BANJIR LAHAR DINGIN MERAPI DI KOTA YOGYAKARTA
}

\author{
Gunardo RB \\ Universitas Negeri Yogyakarta \\ e-mail: pakgunardo@yahoo.com
}

\begin{abstract}
ABSTRAK: Karakter Gotong Royong Warga dalam Menghadapi Bencana Banjir Lahar Dingin Merapi Di Kota Yogyakarta. Tujuan penelitian ini ingin mengetahui aspek kesehatan (penyakit), budaya (gotong royong) dan ekonomi (permukiman dan potensi sumber daya alam) dari peristiwa banjir lahar dingin Merapi di Kota Yogyakarta. Jenis penelitian ini adalah penelitian deskriptif kuantitatif. Teknik pengumpulan data menggunakan dokumentasi, wawancara, dan observasi. Lokasi penelitian di Kelurahan Tegalpanggung dan Kelurahan Suryatmajan. Hasil penelitian menunjukkan bahwa penyakit yang muncul di lokasi penelitin adalah penyakit batuk, diare, sakit kepala, kulit gatal dan demam. Puskesmas mendekatkan pelayanannya dengan mendirikan posko di dekat lokasi bencana. Kegotongroyongan warga terjadi pada saat banjir datang dan pascabanjir lahar dingin. Sementara warga lain menunggu bantuan, warga Kelurahan Tegalpanggung melakukan kerja bakti memasang karung pasir saat banjir dan meninggikan talud secara swadaya. Kerusakan permukiman berupa rusaknya bangunan rumah, sumur menjadi kotor, fasilitas olahraga dan balai pertemuan tertimbun pasir. Warga belum memanfaatkan potensi sumber daya alam pasir, kerikil, dan batu secara ekonomis, baru sebatas untuk keperluan sendiri.
\end{abstract}

Kata Kunci: karakter gotong royong, lahar dingin, bantaran sungai, dan Yogyakarta.

\begin{abstract}
Mutual Cooperation Character of The Citizens in Facing Merapi Cold Lava Flood Disaster in Yogyakarta. The purpose of this research was to determine the health aspects (disease), cultural (mutual aid) and economic (settlements and natural resources) from Merapi cold lava flood in the city of Yogyakarta. This research is descriptive quantitative research. Data collection techniques using documentation, interviews, and observations. Location of the study, in the Village Tegalpanggung, and Village Suryatmajan. The results showed that the disease appeared in the location of the study was disease cough, diarrhea, headache, skin itching and fever. Health center services by establishing a command post set up near the disaster site. Mutual cooperation of citizens, occurs when the floods come and post cold lava flood. While other residents waiting for help, residents in the Village Tegalpanggung perform voluntary work by placing sandbags during floods and elevate talud independently. Damage in the form of damage to residential houses, wells become dirty, sports facilities and meeting places buried in the sand. Citizens have not been utilizing the natural resources of sand, gravel, and stone economically, merely for their own purposes.
\end{abstract}

\section{PENDAHULUAN}

Menurut Badan Geologi dan Vulkanologi DIY erupsi Merapi tanggal 26 Oktober 2010 telah memuntahkan material vulkanik sebesar 140 juta meter kubik (Harian Kompas, 20 November 2010:15). Meskipun bahaya primer berupa lahar panas dan "wedus gembel" sudah berlalu, tetapi ancaman lebih serius muncul dari gelontoran lahar dingin yang akan dibawa sejumlah sungai yang masuk kekawasan perkotaan dan permukiman. Tidak ketinggalan, hal demikian sudah dialami Kota Yogyakarta melalui sungai Code. Banjir lahar dingin pada tanggal 27 November 2010 tergolong besar karena berhasil melewati talud sungai dan merendam 
sebagian rumah penduduk dengan lumpur, pasir, dan batu. Kemudian banjir bulan Desember 2010 juga cukup menimbulkan trauma penduduk yang tinggal di bantaran sungai Code. Kerugian material dialami penduduk cukup besar yang mencapai ratusan juta rupiah (Harian Kedaulatan Rakyat, 28 November 2010). Bahkan Bappeda Kota Yogyakarta melaporkan seluruh potensi kerugian yang meliputi rusaknya rumah, fasilitas umum, sumur, jembatan, talud, dan sanitasi yang mencapai milyaran rupiah. Bukan hanya kerusakan permukiman penduduk saja, tetapi bahaya timbulnya penyakit akibat banjir lahar dingin juga mengancam penduduk.

Sangat menarik bila aspek kesehatan seperti itu dapat diketahui secara lebih lengkap, sehingga perlu kajian tentang aspek kesehatan berkaitan dengan akibat banjir lahar dingin untuk menjawab penyakit-penyakit apa saja yang berpotensi menjadi wabah, daerah-daerah mana saja yang terkena, dan bagaimana mengantisipasi hal tersebut agar tidak merugikan penduduk. Sebagai pihak yang bertanggung jawab terhadap kondisi kesehatan masyarakat, baik saat bencana dan paska bencana, Dinas Kesehatan Kota Yogyakarta, dalam hal ini Pusat Kesehatan Masyarakat di masing-masing Kecamatan, mengambil peran yang sangat penting.

Menarik juga untuk diketahui bagaimana kegotongroyongan penduduk sebagai modal sosial menghadapi bencana banjir lahar dingin pada saat terjadi dan sesudahnya itu. Konon ada perbedaan penerapan kegotongroyongan itu sehingga mengakibatkan perbedaan besar kerusakan yang dialami. Oleh karena itu, kerusakan permukiman yang dialami perlu dikaji, baik di daerah yang masih kental rasa gotong royongnya maupun di daerah yang sudah mulai pudar kegotongroyongannya. Kerusakan permukiman meliputi lantai, dinding, dan genting serta kemungkinan kerusakan harta benda lainnya. Banjir lahar dingin tidak hanya merusak tetapi juga memberikan berkah berupa potensi sumber daya alam berupa pasir, kerikil, dan batu. Bagaimana penduduk menyikapi berkah tersebut perlu dikaji agar potensi sumber daya alam menjadi riil menaikkan kesejahteraan penduduk.

Sungai Code adalah sungai yang berhulu di Sungai Boyong di lereng Gunung Merapi, mengalir melalui Kabupaten Sleman, masuk ke kota Yogyakarta sepanjang $6 \mathrm{~km}$ melalui 8 Kecamatan dan 14 Kelurahan. Sungai Code mengalami pendangkalan berkisar $70 \mathrm{~cm}$ hingga satu meter akibat banjir lahar dingin (Harian Kedaulatan Rakyat, 4 Desember 2010). Banjir lahar dingin yang terjadi tanggal 27 November 2010 telah merusak permukiman penduduk dan mengancam 13.000 jiwa yang bermukim di bantaran Sungai Code (Harian Kedaulatan Rakyat, 9 November 2010). Lahar dingin berpotensi merusak bangunan perumahan seperti yang terjadi di Shimabara Jepang ketika Gunung Unzen meletus tahun 1991 (Keller \&cBlodgett, 2006). Akan tetapi menurut Sutikno dkk. peristiwa erupsi yang banyak terjadi di samping menyebabkan timbulnya bahaya, juga menghasilkan potensi sumber daya yang dapat dimanfaatkan untuk mendukung dinamika kehidupan di dalamnya. Salah satu sumber daya yang potensial adalah sedimen baik dari aliran lava, aliran debu dan gas, serta aliran piroklastik (Sutikno dkk., 2007: 6). Bahkan warga Kelurahan Prawirodirjan telah menjual pasir dari sungai Code per karung Rp. 2.000,- dan Kelurahan Kotabaru menerima fee sebesar Rp. 60.000,- per rit truk dari pengusaha yang menambang di Sungai Code wilayah Kelurahan Kotabaru Kecamatan Gondokusuman (Harian Kedaulatan Rakyat, 10 Januari 2011: 7).

Pengusaha telah bersepakat dengan warga sekitar sungai yang ditambang dengan pertimbangan pasir yang dikeruk dengan alat berat (backhoe) akan mengurangi pasir yang masuk ke rumah dan lingkungan sekitar. Tentu hal ini akan mengurangi kecemasan warga. Banjir lahar dingin akan mengontaminasi air bersih (sumur), saluran pembuangan air limbah rumah tangga mampet, saluran air hujan juga mampet (Harian Kedaulatan Rakyat, 26 November 2010). Kontaminasi air sumur berupa kandungan 
logam berat yang meengendap di dasar sumur. Menurut Junun, pengurasan merupakan satu-satunya cara untuk menghilangkan logam berat dalam sumur (Harian Kompas, 16 November 2010). Logam berat itu adalah kadmium dan tembaga yang sangat berbahaya bagi kesehatan. Untuk mengatasi berbagai masalah itu warga perlu bergotong royong sebagai konteks pemberdayaan. Sesungguhnya karakter gotong royong warga sudah ada sejak lama dan menjadi modal sosial yang besar di masyarakat. Terlebih di kota Yogyakarta yang menjadi kota revolusi, antara tahun 1945 hingga 1950, terasa karakter gotong royong warga Kota Yogyakarta berhasil merebut dan mempertahankan kemerdekaan dari rongrongan penjajah Belanda. Meskipun senjata Belanda lebih canggih dan masyarakat hanya menggunakan bambu runcing, pedang atau tombak peninggalan nenek moyang, tetapi semangat gotong royong telah mampu mengusir Belanda. Kegotongroyongan itu tampak ketika laskar-laskar dibentuk yang dengan spontan pemuda-pemudi mendaftar, tanpa menanyakan upah. Ketika mereka terpaksa lari ke desa-desa, warga desa serentak menyediakan nasi bungkus (nuk) dan air kendi sebagai logistik bagi para pejuang.

Warga desa juga menunjukkan karakter gotong royong. Sungguh karakter gotong royong sudah ada dan menjadi milik warga sebagai modal sosial dalam bermasyarakat. Sayang di zaman teknologi ini, karakter gotong royong disinyalir tergerus oleh sifat individualis, materialis, dan hedonis. Tulisan ini akan mengungkap bagaimana karakter gotong royong muncul ketika bencana menimpa dan menjadi solusi yang tepat. Harapannya karakter gotong royong dapat dibangkitkan kembali di tengah-tengah warga masyarakat.

\section{METODE}

Penelitian ini adalah penelitian deskriptif kualitatif. Langkah-langkah penelitian yang akan dilaksanakan meliputi: observasi, yakni cara dan teknik pengumpulan data dengan melakukan pengamatan dan pen- catatan secara sistematis terhadap gejala atau fenomena yang ada pada proyek penelitian (Tika, 2005: 44). Metode ini digunakan untuk mencari data awal tentang daerah penelitian, untuk mendapatkan gambaran umum daerah penelitian dengan memperhatikan keadaan riil atau fenomena yang ada di lapangan. Peneliti telah mengamati 14 kelurahan yang kemudian 3 kelurahan yaitu Kelurahan Gowongan, Kelurahan Tegalpanggung, dan Kelurahan Suryatmajan dijadikan sebagai sampel. Ketiga kelurahan tersebut yang paling banyak mengalami kerusakan akibat banjir lahar dingin dan mempunyai dampak sosial ekonomi lebih lengkap. Secara teknis lebih mudah dijangkau karena ketiga kelurahan letaknya berdekatan. Pengumpulan data kerusakan pemukiman dan lingkungan menggunakan kamera untuk merekam kondisi terakhir akibat banjir lahar dingin. Sedangkan data kesehatan dan kegotongroyongan warga dikumpulkan dengan daftar kuisioner dan melakukan wawancara dengan Kepala Puskesmas terdekat dan warga setempat serta beberapa tokoh masyarakat yang terlibat langsung penanganan saat terjadi banjir lahar dingin dan sesudahnya. Data yang terkumpul kemudian dianalisis dengan menggunakan tabulasi dan persentase sehingga tingkat kerusakan permukiman, kuantitas penyakit maupun kecenderung an gotong royong warga serta potensi ekonomi sumber daya alam dapat terukur.

\section{HASIL DAN PEMBAHASAN}

Sungai Code mengalir ke dalam Kota Yogyakarta dari arah Utara mulai dari Kelurahan Karangwaru Kecamatan Tegalrejo, Kelurahan Cokrodiningratan dan Kelurahan Gowongan Kecamatan Jetis, Kelurahan Terban dan Kelurahan Kotabaru Kecamatan Gondokusuman, Kelurahan Suryatmajan dan Kelurahan Tegalpanggung di Kecamatan Danurejan, Kelurahan Ngupasan dan Kelurahan Prawirodirjan Kecamatan Gondomanan, Kelurahan Purwokinanti Kecamatan Pakualaman, Kelurahan Keparakan, Kelurahan Wirogunan dan kelurahan Brontokusuman 
Kecamatan Mergangsan, dan Kelurahan Sorosutan Kecamatan Umbulharjo. Secara ringkas Sungai Code mengaliri 8 Kecamatan dari 14 Kecamatan, 14 Kelurahan dari 45 Kelurahan di seluruh Kota Yogyakarta. Dengan demikian, 57\% kecamatan dan 31\% kelurahan menderita akibat banjir lahar dingin Merapi pascaerupsi bulan Oktober 2010, hanya Kelurahan Karangwaru Kecamatan Tegalrejo yang mempunyai kerusakan terkecil, yaitu hanya 3 rumah rusak akibat banjir lahar dingin karena merupakan tebing sebelah Barat Code dan panjangnya kuranglebih 200 meter saja dari panjang sungai Code yang kurang lebih 6 km di Kota Yogyakarta.

Melalui observasi di daerah penelitian ditemukan tingkat kerusakan yang dialami Kelurahan Keparakan, Wirogunan, dan Sorosutan, yakni hanya 5, 15 dan 7 rumah rusak ringan, bahkan Kelurahan Cokrodininratan tidak mempunyai catatan kerusakan rumah, kecuali talud yang rusak di RW 07 dan RW 05. Di kelurahan lainnya tingkat kerusakannya bervariasi mulai dari 25 rumah sampai 161 rumah. Kondisi cukup parah dialami RW 10 Kelurahan Gowongan yang lebih dikenal dengan nama kampung Jogoyudan, yakni seluruh 51 rumah mengalami rusak parah. Demikian juga, di Kelurahan Tegalpanggung dan Kelurahan Suryatmajan cukup parah tingkat kerusakan permukimannya. Oleh karena itu, penelitian difokuskan di tiga kelurahan tersebut agar diperoleh data tentang dampak sosial ekonomi banjir lahar dingin Merapi, terutama data kerusakan permukiman, lingkungan, penyakit, dan persebarannya, kegotongroyongan warga, dan potensi sumber daya alam.

\section{Kerusakan Permukiman.}

Di wilayah kampung Jogoyudan Kelurahan Gowongan Kecamatan Jetis Kota Yogyakarta, terutama RW 10 hampir seluruh rumah sebanyak 51 mengalami rusak berat. Banjir sekitar jam 5 sore hingga jam 9 malam sungguh mengerikan karena datang dari arah barat dan timur sekaligus. Air bah yang menghantam tebing timur di bagian utara kampung berbelok arah dengan cepat melompati talud yang tingginya cuma 1,5 meter menyusuri tebing di arah barat permukiman dan mengalir deras dari arah barat menyapu seluruh rumah yang ada di RW 10. Apalagi dari arah timur air juga semakin tinggi melewati talud membawa lumpur pasir dan kotoran merendam rumah warga. Air bah tadi membawa material batu dan kayu yang menghancurkan genting, jendela dan pintu rumah-rumah di sini. Tidak ada satu pun rumah yang utuh, dan pintu serta jendela lepas dari engselnya. Warga tidak sempat menyelamatkan harta benda. Semua warga lari ke wilayah RW 06 dan 07 yang relatif tinggi dan tidak terkena air bah. Ada pos ronda, balai kampung yang dipakai untuk mengungsi atau ke saudara dan tetangga yang menyediakan ruang di rumahnya untuk ditempati.

Di Kelurahan Tegalpanggung yang terletak di sebelah timur sungai Code, sebelah selatan kampung Jogoyudan, banjir telah masuk ke RW 01, RW 02, RW 03, RW 13, RW 14 atau 5 RW dari 16 RW yang ada. Kondisi yang paling parah dialami RW 02 dan RW 03 karena letaknya relatif lebih rendah. Banjir melanda 88 rumah di RW-RW (33 rumah di RW 02 dan RW 03) yang terletak di pinggir sungai Code. Tingkat kerusakan bangunan rumah yang dialami 33 rusak berat, 30 rusak sedang, dan 25 rusak ringan. Banjir pertama, saat talud masih setinggi 2,5 meter dari dasar sungai, tingginya sampai 3 meter sehingga meluap sampai berjarak 60 meter dari talud.

Setelah banjir surut, ternyata dasar sungai telah naik setinggi rata-rata 1,5 meter sehingga tinggi talud tinggal 1 meter. Warga kemudian memasang kantong-kantong berisi pasir di atas talud hingga setinggi 1 meter. Namun, banjir kedua dan seterusnya air tetap meluap dan menghancurkan kantongkantong pasir. Walaupun hanya semalam, tetapi kecemasan nampak di wajah-wajah mereka, terutama anak-anak kecil. Air banjir bercampur lumpur masuk ke rumah sampai setinggi pinggang orang dewasa. Meskipun demikian, tidak ada rumah yang rusak kare- 
na banjir. Genangan air yang menyurut menyisakan pasir dan lumpur yang cukup tebal antara $10 \mathrm{~cm}$ sampai $30 \mathrm{~cm}$. Lumpurnya berbau belerang dan menyebabkan batukbatuk bagi beberapa orang.

Adapun banjir di Kelurahan Suryatmajan hanya menimpa 35 rumah di RT 07, 08,dan 10. Kriteria rusak berat menimpa 3 rumah, rusak sedang 32 rumah dan rusak ringan tidak ada. Rumah yang terendam lumpur hingga 2 meter ada 15 rumah yang ditinggal penghuninya karena sudah tidak layak huni, apalagi banyak genting yang hancur, serta jendela dan pintu rusak. Mereka belum mempunyai biaya untuk memperbaiki rumah. Adapun rumah yang hanya terendam kurang dari $50 \mathrm{~cm}$, segera dibersihkan dan sudah dihuni kembali.

\section{Kerusakan Lingkungan}

Baik di Kelurahan Tegalpanggung, Suryatmajan, maupun Gowongan banyak sanitasi rusak dan halaman yang terendam lumpur serta pasir menggenang air di sana sini, bahkan seperti ada mata air baru. Halaman menjadi becek dan menimbulkan rasa tidak nyaman. Di Kelurahan Gowongan tepatnya di kampung Jogoyudan balai RW terendam dua meter sehingga tidak dapat digunakan untuk kegiatan warga. Lapangan voley dan badminton rusak parah. Seluruh wilayah yang terendam banjir bercampur pasir dan lumpur mengalami ketinggian permukaan tanah antara 1 sampai 2 meter, sehingga permukaan tanah di wilayah Jogoyudan relatif menjadi datar. Usaha untuk mengeruk lumpur yang sudah mengeras setinggi 2 meter nampaknya terlalu berat untuk warga, sehingga sebagian besar menyesuaikan diri dengan kondisi yang ada. Artinya, ada yang meninggikan rumahnya atau sekedar membongkar langit-langit untuk memberi kesan luas. Balai RW diratakan saja tanahnya, hingga tangga lama sudah tidak berguna lagi. Demikian pula lapangan voley dan badminton tingginya menyesuaikan dengan keadaan dan tiang jaring dinaikkan sesuai dengan peraturan olahraga tersebut. Di sumur-sumur yang ada terpaksa diadakan pengurasan terlebih dahulu sebelum dapat dipergunakan lagi.

Di Tegalpanggung, warga bantaran Code (RW 01, 02, 03, 13 dan 14) menerima bantuan pompa air untuk menyedot dan membersihkan sumur yang tercemar oleh banjir. Bantuan berasal dari dana pemerintah melalui LPMK. Pihak Kelurahan menyalurkan bantuan sekop, serok, dan alat-alat lain dari para dermawan. LPMK juga memberi bantuan semen bagi warga yang ingin meninggikan lantainya agar tidak terendam banjir lagi. Kerusakan lingkungan dialami RW 03 yaitu lapangan badminton terendam lumpur setinggi $50 \mathrm{~cm}$ dan mengeras, sehingga warga enggan mengeruknya.

Kelurahan Suryatmajan, tepatnya di kampung Gemblakan Bawah yang terkena bencana banjir, tidak terlalu banyak fasilitas lingkungan yang rusak. Sumur-sumur yang tadinya tercemar, segera dibersihkan dan sudah dapat dipergunakan lagi. Dibanding Tegalpanggung dan Gowongan, wilayah yang terkena banjir di Suryatmajan relatif lebih sempit, sehingga kerusakannya relatif sedikit pula. Balai RW hanya terendam air banjir selama 6 jam, setelah dibersihkan bersama-sama segera dapat digunakan untuk rapat-rapat dan pertemuan yang lain

\section{Penyakit dan Persebarannya}

Puskesmas Danurejan I yang wilayah kerjanya meliputi Kelurahan Tegalpanggung memberi data tentang penyakit-penyakit yang muncul pascabanjir dan penanganannya. Menurut petugas Puskesmas, penyakit yang muncul sebagian besar ISPA (Infeksi Saluran Pernapasan Atas) yaitu batuk-batuk, kemudian diare, demam, sakit kepala dan penyakit kulit semacam rangen yang terasa panas dan gatal. Sebagian besar penderita adalah wanita usia tua dan anak-anak balita. Air banjir memang terasa bau belerang yang mengganggu kesehatan warga. Puskesmas DN I membuka Pos di dekat Jembatan Jambu untuk beberapa hari. Mobil ambulance siaga 24 jam, dokter dan perawat siaga bergantian. Puskesmas DN II membuka Pos di balai RW Gemblakan Atas Kelurahan Suryatmajan. 
Penyakit batuk-batuk menduduki rangking teratas dari jumlah penderita yang berobat ke Posko, yaitu 60 orang dari 146 penderita atau $41 \%$. Penyakit diare diderita 36 orang atau $24,6 \%$, mayoritas orang dewasa, karena kelelahan waktu menanggulangi banjir dan kegiatan bersih-bersih setelah air surut. Perlu diketahui bahwa letak Puskesmas II berada di Kelurahan Bausasran paling Utara, berjarak kurang lebih $2 \mathrm{~km}$ dari wilayah yang terkena banjir lahar dingin. Jadi sudah sangat tepat ketika Puskesmas DN II memutuskan membangun Posko Kesehatan di balai RW Gemblakan Atas yang sangat dekat dengan daerah banjir, tetapi lokasinya di tempat yang tinggi sehingga aman dari banjir dan dapat memberi pengobatan secepat mungkin kepada penduduk. Penduduk juga cukup berjalan kaki tidak lebih 10 menit untuk sampai di posko kesehatan.

Puskesmas Jetis membuka pos di kampung Jogoyudan Kelurahan Gowongan di RW 7 yang terletak di bagian atas yang bebas dari banjir. Mobil ambulance selalu siaga ketika banjir datang. Tampaknya Puskesmas Jetis cukup tanggap dan mendekatkan pelayanannya kepada masyarakat. Persediaan obat-obatan cukup tersedia setelah mendapat tambahan dari Dinas Kesehatan Kota Yogyakarta. Warga cukup berobat ke posko karena jarak ke Puskesmas Jetis cukup jauh, kurang lebih 1,5 km. Setiap hari dokter dan perawat praktek di Posko dari pagi hingga sore paska banjir. Persediaan obat mencukupi karena Dinas Kesehatan Kota selalu memenuhi permintaan kebutuhan dari Puskesmas saat dan paska banjir.

Kesigapan staf Puskesmas dalam melayani masyarakat langsung ke lokasi banjir dan tidak menunggu di kantor patut diapresiasi dan merupakan bukti besarnya tanggung jawab terhadap warga yang menderita sakit akibat banjir. Tanggung jawab merupakan salah satu karakter yang patut dipertahankan dan dikembangkan untuk mengatasi berbagai masalah.

\section{Kegotongroyongan Warga}

Peristiwa banjir lahar dingin telah mengembalikan lagi karakter gotong royong warga Yogyakarta. Sebagai contoh di kampung Ledok Tukangan pada banjir yang terjadi tanggal 27 November 2010, seluruh warga bergotong royong mencoba menahan luapan air bah dengan mengisi karung dengan pasir. Karung diperoleh dari pihak kecamatan dan kelurahan yang selalu menyediakan karung dan beberapa warga sendiri menyumbangkan karung berasnya yang sudah tidak terpakai. Hampir seratus orang kerja bakti, mulai dari orang tua, dewasa, pemuda pemudi, dan anak-anak terlibat semua. Tanpa dikomando, mereka secara suka rela mengeruk pasir dengan alat seadanya, yang lain menampung dengan karung terbuka. Setelah penuh, orang mengangkatnya dan memberikannya kepada warga yang siap menghadang banjir dengan karung berisi pasir. Tumpukan pasir makin tinggi, meskipun kadang-kadang karung itu terpental karena derasnya air sungai. Meskipun demikian, warga tetap memasang kembali secara berulang-ulang sehingga tumpukan karung berhasil menahan luapan banjir dan warga terlihat ceria melihat hasilnya yang menggembirakan.

Sementara warga berjuang menahan luapan banjir, tanpa dikomando ibu-ibu kemudian berinsiatif mengumpulkan beras, sayur, bumbu, lauk pauk, membuka dapur umum darurat, dan segera memasak serta membungkusnya sebagai nasi nuk dan air teh pun dimasak. Tidak peduli ibu-ibu muda atau tua, kaya atau miskin, suku apa saja (di kampung Ledok Tukangan tinggal suku Batak, Cina, Sunda, Padang, Madura, dan tentu saja suku Jawa), dan agama yang dianut, serentak dapat terlihat karakter asli bangsa Indonesia, yaitu gotong royong. Inilah modal dasar pembangunan yang telah dilupakan bangsa Indonesia sehingga negara kita masih terbelit korupsi, kemiskinan, dan keterbelakangan. Sekitar dua jam, setelah warga berjuang menahan air dengan menanggul talud dengan tumpukan karung berisi pasir, warga dapat menikmati nasi 
hangat dan teh panas. Saat itu bantuan tenaga dari TNI AD berdatangan dari berbagai markas. Mereka mendirikan posko dengan memasang tenda di pinggir sungai. Tentara yang masih muda ikut bergabung, membaur dengan masyarakat, dan makan nasi nuk yang disediakan ibu-ibu. Suasana menjadi akrab dan penuh canda. Mereka ditugasi oleh komandan mereka untuk ikut menjaga keamanan dan bekerja bakti. Bisa dimaklumi dalam kondisi panik, banjir dan gelap terkadang ada yang memanfaatkan situasi untuk keuntungan diri sendiri.

Orang-orang tua mengingat kegotongroyongan warga seperti yang ada pada zaman perang kemerdekaan. Ketika pejuang warga lari ke desa-desa karena dikejar Belanda. Warga desa menyediakan nuk nasi dengan air kendi yang segar, tanpa menyodorkan kuitansi. Warga rela menyumbang untuk kepentingan bangsanya. Terasa kegotongroyongan warga masih kental. Inilah modal sosial warga kampung Ledok Tukangan terutama RW 01, karena warga RW 02 tidak terlihat usaha menahan banjir. Mereka mengungsi ke Balai Serba Guna. Para orang tua masih ingat zaman sebelum ada RW (Rukun Warga) tahun 1984, kampung Ledok Tukangan adalah satu wilayah yang dipimpin Ketua RK (Rukun Kampung). Rukung Kampung adalah lembaga sosial di bawah kecamatan (dulu bernama kemantren pamong praja) insiatif Sultan Hamengku Buwono IX untuk memperkuat jaringan sosial warga kota Yogyakarta. Menggunakan kata Rukun, karena dalam setiap keputusan yang menyangkut wilayah pasti berdasarkan musyawarah warga dalam suasana rukun. Oleh karena itu, zaman RK pembangunan balai wilayah, pengerasan jalan-jalan kampung, saluran air hujan, sarana olahraga berlandaskan pada swadaya masyarakat yang besar. Kebutuhan masyarakat seperti upacara kelahiran bayi, khitanan, perkawinan, dan kematian semua ditanggung bersama-sama dalam bentuk gotong royong seluruh warga. Hidup dalam suasana gotong royong sungguh terasa nikmat. Bahkan pembangunan rumah pun dilaksanakan dengan gotong royong. Kalau sekarang suasana sudah berubah, perlu direnungkan kembali semangat gotong royong sebagai kekuatan masyarakat menghadapi berbagai problema hidup.

Di Ledok Tukangan warga selalu resah manakala mendung gelap menyelimuti lereng Merapi karena bahaya banjir yang kemungkinan besar terjadi mengingat potensi material yang masih menumpuk di lereng Merapi konon mencapai 130 juta m3. RW 02 memilih menunggu bantuan pemerintah, karena menurut mereka bencana ini menjadi tanggung jawab pemerintah. Barangkali ini imbas dari pemerintah sendiri yang selalu memberikan bantuan gratis kepada warga sehingga insiatif warga menjadi lemah. Salah satu tokoh masyarakat memang mengatakan sudah begitu lama warga dininabobokkan dengan berbagai bantuan. Misalnya, mau makan ada beras miskin (raskin), mau sekolah ada BOS (bantuan operasional sekolah), mau sakit ada jamkesmas (jaminan kesehatan masyarakat), dan yang paling parah BLT (Bantuan Langsung Tunai). Mereka tidak pernah ditanya tiba-tiba diberi uang Rp.100.000 per bulan. Karena tidak semua dapat, maka timbul kecemburuan sosial. Biarlah yang kerja bakti yang dapat uang saja. Warga RW 02 mungkin berpikir, semua adalah tanggung jawab pemerintah. Padahal pemerintah mempunyai birokrasi yang baku, yang untuk membangun sesuatu perlu usulan, pembahasan di DPRD, diputuskan bersama Pemerintah Kota, yang kemudian dianggarkan dan dilaksanakan. Untuk pembangunan itu diperlukan waktu minimal setahun, mulai dari rencana hingga pelaksanaannya. Sedangkan warga merasa cemas setiap hari, apalagi bila mendung di atas Merapi. Oleh karena itu, warga RW 01 berinisiatif mengumpulkan seluruh warga untuk bermusyawarah menanggulangi bencana. Rapat warga di mesjid cukup ramai dengan berbagai pendapat. Dari alternatif meninggikan lantai rumah, pindah tempat atau meninggikan talud warga memilih meninggikan talud. Atas dasar kesepakatan bersama, dibentuklah Panitia Penanggulan- 
gan Banjir RW 01 untuk peninggian talud setinggi 1,5meter dan sepanjang 50 meter. Dana yang diperlukan Rp.12.000.000,- Saat itu pula warga spontan mengacungkan tangan memberi sumbangan.

Sikap spontan adalah ciri khas karakter gotong royong di masyarakat. Tidak perlu banyak pertimbangan dalam pelaksanaannya, kecuali apa yang dapat disumbangkan untuk mengatasi masalah bersama. Dari seluruh warga RW 01 terkumpul dana Rp.4.225.000,- yang segera diterapkan untuk membeli semen, batako, dan besi, yang secara gotong royong dikerjakan untuk peninggian talud. Secara kebetulan di antara warga ada yang menjadi tukang batu sehingga mereka secara langsung melaksanakan pemasangan besi sebagai tulang, dan mengaduk semen, dan pasir sebagai betonnya. Dalam waktu tiga hari warga bekerja secara bersama meninggikan talud. Saat hasil kerja mencapai sepanjang 5 meter, dibuatkan proposal permohonan bantuan kepada para dermawan disertai dengan foto-foto hasil gotong royong warga. Hasilnya luar biasa, karena dana yang diper- oleh melebihi kebutuhan, yakni mencapai sekitar Rp.25.000.000,-. Tercatat beberapa bantuan mengalir dari beberapa hotel di wilayah Danurejan, calon walikota Yogyakarta, partai politik, anggota DPRD, karyawan PT. KAI, lembaga-lembaga zakat dan dosen-dosen UNY secara pribadi. Akhirnya RW 01 berhasil meninggikan talud sesuai dengan rencana dan bahkan membantu RW lain dalam bentuk uang dan material untuk meningggikan talud. RW lain pun ketularan bergotong royong dan meninggikan talud sejajar dengan talud di RW 01, karena mereka khawatir bila talud di RW 01 sudah ditinggikan, bila terjadi banjir maka air bah akan langsung masuk ke wilayah RW 02 dan 03 yang taludnya masih rendah. Oleh karena itu, warga RW 02 dan 03 pun segera meninggikan talud. Jalan di pinggir talud pun diperbaiki dengan dana bantuan donatur. Kantor Badan Lingkungan Hidup Kota Yogyakarta membantu tanaman-tanaman dalam pot yang secara asri diletakkan di pinggir talud. Ternyata semangat gotong royong warga dapat menyelesaikan masalah bersama. Sekarang warga tidak was-was lagi

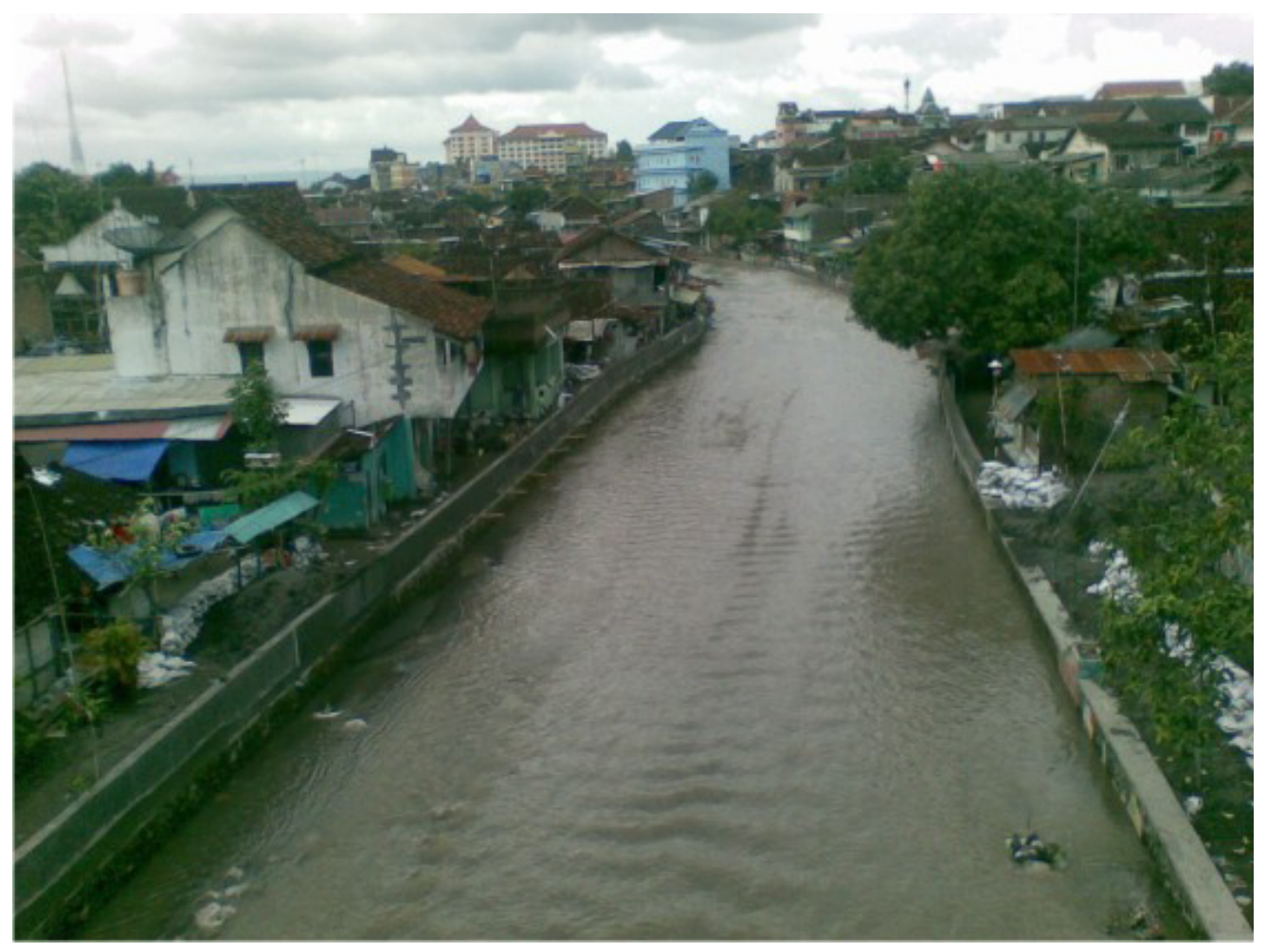

Gambar 1. Kampung Ledok Tukangan (kiri) dan

Kampung Gemblakan (kanan) Pascabanjir 
menjalani hidup, meskipun cuaca di lereng Merapi diliputi mendung.

Kegotongroyongan warga di Kampung Gemblakan ikut terlibat langsung dalam penanganan pengungsi karena rumah mereka terendam banjir. Ada 15 kepala keluarga yang harus mengungsi ke bagian atas dari kampung Gemblakan karena rumah mereka terendam air sekitar 2 meter. Dari kantor Kecamatan Danurejan dibagikan beras, kecap, dan mie ke kantor kelurahan, kemudian diteruskan ke RW-RW yang mengalami banjir lahar dingin. Ada RW yang lalu membuka dapur umum, tetapi ada pula yang langsung membagi ke keluarga yang menjadi korban banjir. Dapur Umum yang terdiri dari relawan ibu-ibu bertugas memasak setiap hari, membungkusnya, membagikan nasi dan air teh ke warga yang belum sempat bekerja karena kebanjiran. Lumpur di dalam rumah sudah mengeras dan sulit dibersihkan. Akan tetapi penanganan rumah warga yang terkena banjir dilakukan sendiri-sendiri. Belum ada insiatif dari warga, ketua RT atau ketua RW untuk mengerahkan warganya bergotong royong.

Di kampung Jogoyudan Kelurahan Gowongan Kecamatan Jetis warga sepenuhnya menunggu bantuan dari dermawan dan pemerintah untuk menyambung hidup. Pemerintah menyalurkan bantuan beras, mie instan, kecap, minyak goreng, dan lain-lain secara cukup ke seluruh warga. Akan tetapi, untuk perumahan tampaknya baru didata, sehingga belum ada bantuan riil pembangunan rumah, kecuali sekop dan cangkul untuk membersihkan halaman dan mengeluarkan lumpur dari dalam rumah. Setiap minggu warga sepakat bergotong royong membersihkan lingkungannya. Mulai dari Balai RW, lapangan olah raga volley dan badminton serta jalan-jalan kampung dibersihkan dan dirapikan untuk mempermudah lalu lintas setempat.

Kondisi wilayah yang terkena banjir di sekitar sungai Code dapat dilihat dalam gambar di atas. Pada gambar di atas tampak kampung Ledok Tukangan di sebelah kiri telah berhasil meninggikan talud berkat kara- kter gotong royong warganya, sedangkan talud di Gemblakan Suryatmajan sebelah kanan belum ditinggikan dan masih tampak karung-karung berisi pasir. Karakter gotong royong yang secara jelas berhasil mengatasi masalah seharusnya menjadi pertimbangan pemerintah, agar setiap rencana pembangunan di wilayah melibatkan warga setempat. Hasil pembangunan akan lebih baik, karena warga merasa memiliki dan ikut bertanggung jawab serta menikmati hasilnya. Karakter gotong royong akan mendorong kemajuan warga lebih cepat mencapai kesejahteraan.

\section{Potensi Sumber Daya Alam}

Erupsi Merapi akhir bulan Oktober hingga bulan November 2010 yang diikuti banjir lahar dingin telah menimbulkan bencana, tetapi sekaligus berkah kekayaan sumber daya alam yang luar biasa besarnya. Para ahli memperkirakan selama proses erupsinya, Merapi mengeluarkan material berupa piroklastik sebanyak 140 juta meter kubik. Material piroklastik terdiri dari debu, pasir, kerikil, krakal, batu hingga bongkahan batu besar.

Sampai banjir bulan Februari 2011 baru 15 juta meter kubik yang berhasil turun melalui sungai-sungai yang berhulu di lereng Merapi. Berarti masih ada 125 juta meter kubik yang siap turun. Di samping potensi bahaya, material piroklastik adalah sumber daya alam yang banyak gunanya. Ketika warga Code meninggikan talud, maka material pasir tinggal ambil saja, tidak usah mengeluarkan uang. Sesungguhnya dengan bermodal gotong royong, pasir dan material di sungai dapat dijadikan batako konblok atau pot tanaman dan industri berbahan baku pasir dan batu, sehingga dapat meningkatkan pendapatan warga pinggir sungai Code.

\section{SIMPULAN}

Setelah pengumpulan data, analisis data dan penafsiran hasil penelitian, dapat dikemukakan kesimpulan sebagai berikut: 
1. Penyakit yang muncul akibat banjir lahar dingin adalah penyakit ISPA (infeksi saluran pernapasan atas), batuk, diare, demam, dan kulit gatal. Puskesmas mengantisipasinya dengan membuka Pos Kesehatan langsung ke dekat lokasi yang terkena bencana banjir dengan persediaan obat yang cukup. Tanggung jawab petugas Puskesmas adalah karakter gotong royong yang harus terus dikembangkan.

2. Kerusakan rumah penduduk terutama akibat derasnya air banjir lahar dingin diikuti batu dan kayu yang menghantam rumah sehingga genting-gentingnya pecah, pintu dan jendela terlepas, serta terendam lumpur yang mengeras. Sampai kini masih ada yang belum kembali ke rumahnya karena belum merehabilitasi rumahnya. Pemimpin lokal (Ketua RTdan RW) dapat memobilisasi warganya dengan sifat gotong royong untuk merehabilitisasi bangunan yang rusak.

3. Lingkungan yang rusak antara lain fasilitas Balai RW yang terendam, lapangan volley-badminton yang ketinggiannya naik hampir 2 meter, air sumur yang menjadi kotor dan bau belerang. Di beberapa tempat muncul mata air yang menggenang, sehingga terasa becek dan kotor. Kiranya kerusakan ini dapat diperbaiki dengan semangat gotong royong.

4. Sikap masyarakat saat menghadapi banjir ditunjukkan oleh warga Ledok Tukangan RW 01 dengan meninggikan talud menggunakan karung diisi pasir oleh seluruh warga (bapak, pemuda, dan anak-anak), sedang ibu-ibu membuka dapur umum darurat memasak (bahannya sumbangan warga sendiri) dan ketika banjir, kedua tanggul pasir itu jebol tidak kuat menahan derasnya air bercampur lumpur dan batu, warga sepakat meninggikan talud dengan cara urunan sebagai bukti swadaya dan mengajukan bantuan ke berbagai pihak di luar kampung (wujud kegotongroyongan). Karakter gotong royong warga ternyata berhasil menghadapi bencana banjir. Karakter gotong royong yang dimiliki warga sebagai modal sosial mengatasi masalah tampak dari sifat spontanitas, mengulurkan bantuan tenaga atau materi, berpikirnya hanya aku dapat menyumbangkan apa dan serta merta melaksanakannya.

5. Sikap masyarakat terhadap potensi sumber daya alam berupa pasir dan batu belum maksimal. Ada di antara mereka yang mengumpulkan pasir dan dijual per karung, tetapi hal itu hanya bersifat insidental.

\section{DAFTAR PUSTAKA}

Harian Kedaulatan Rakyat Yogyakarta, tanggal 9 November 2010, 26 November2010, 28 November 2010, 4 Desember 2010, dan 10 januari 2011.

Harian Kompas. Jakarta, tanggal 16 November 2010, dan 20 November 2010. www. jogjakarta.go.id

Keller, Edward A. \& Blodgett, Robert H. 2006. Natural Hazards. New York: Pearson Prentice Hall.

Sutikno dkk. 2007. "Potensi Sumber Daya Alam Gunung Api Merapi dan Pengelolaannya Untuk mendukung Kehidupan Masyarakat Sekitar". Laporan Penelitian. Yogyakarta: Fak. Geografi UGM.

Tika, Pabundu. 2005. Metodologi Penelitian Geografi. Jakarta: Bumi Aksara. 